\title{
Democratization, Globalization and Women's Empowerment: A Critical Review and Conceptual Framework
}

\author{
Barbara Wejnert*
}

\begin{abstract}
This manuscript attempts to provide an answer to several theoretical questions concerning the interaction between the processes of democratization and globalization, and women's empowerment. By integrating conceptual models of political processes and global market economic development, this study overviews several mechanisms of democratization and globalization that could lead to women's empowerment but may fall short of actual positive outcomes for women. The critical review and derived conceptual framework groups political and economic variables to explain why the benefits of democracy and globalized development are not equally distributed across genders. Consequently, this critical review can be used to address the implications for future research on, and policy making for, women's empowerment.
\end{abstract}

\section{INTRODUCTION}

Two trends have dominated the world since the 1970s - the rapid diffusion of democracy and the proliferation of globalized development-defined as countries' level of development through the spread of the global market economy (Przeworski et al., 2000). There is a pervasive belief that these two trends interact, that liberal democracy, human rights, and equality go hand-in-hand with being modern and with adopting a global market economy.

\footnotetext{
*College of Arts and Sciences

State University of New York, University at Buffalo.

12 Capen Hall, Buffalo, New York 14260-1660,

United States of America.

Email: bwejnert@buffalo.edu
}

Accordingly, since the turn of the millennium, many studies have focused on the relations between people's quality of life, democracy, and development (Kapstein \& Converse 2008; Przeworski et al 2000; Przeworski 2010), as well as on the positive impact of democratization on development and societal well-being (Garrett 2004; Shafer 1994). These studies indicate generally that both trends have brought substantial improvements in people's lives, where democracy and modern development are paths to increased levels of literacy, education, industrialization, urbanization, and overall wellbeing of citizens. Accordingly, democratic growth is considered a symbol of progress, wealth, a high standard of living, freedom, liberty, and happiness, as well as a sign of modernity and the forces that advance the technological and cultural progress of world societies (Lipset 1960, 1994; Joffe, 2009). Furthermore, economic problems are believed to be ameliorated with the adoption of democracy (Lederer, 1992), leading financial institutions often to require that countries democratize in order to receive financial aid or to be eligible for foreign investment (Robinson, 2004; Wolf, 2001).

One might assume that the global growth of democracy and economic globalization (i.e., a global spread of market economy) across the recent decades would improve the well-being of women, and in turn lead to women's empowerment, as reflected by increases in their representation in the workforce, equal pay for equal jobs, equal educational opportunities, improvement in women's health care, longer life expectancy, higher decision making power in familied and comunities, greater political 
participation, and overall womne's higher social position. Indeed, in the long term, women do achieve improvement in countries that achieve a high level of development and democracy (Molina and Purser, 2010) and gain political rights in democracies (Fallon 2003, 2010; Fallon et al. 2012). In turn, once empowered, women significantly contribute to improvements resulting from democracy and development in terms of (i) increased education and decreased dropout rates of their daughters (Coleman, 2004; Kabeer, 2005; Luz and Agadjanian 2015; Shahidul, 2013); (ii) increased ratios of girl-toboy enrolment in primary and secondary education, which directly increases a country's GNP (Hill and King, 1995; United Nations Millennium Project, 2005: 47); (iii) increased autonomy in health decisions regarding maternal and family health and fertility (Beer 2009; Murthy, 1996), which leads more generally to increases in societal health (Bloom, Wypij and Gupta, 2001) and a decline in child mortality (Gakidou, 2010); (iv) increased participation in the labor force (Beer 2009); (v) increased engagement in civil society, including feminist movements that demand gender equality and advancement of women's rights (Chattopadhyay and Duflo, 2004; Fallon, 2010); (vi) increased political and legal awareness and engagement in national politics, thereby establishing policies that protect minorities (Murthy, 1996; Rueschmeyer 1998; Tripp, Casimiro, Kwesiga and Mungwa, 2014); and (vii) increased input into policymaking, which typically invests in areas relevant to families (Bertrand, Duflo \& Mullainathan, 2002).

However, there are recent findings that are discordant with conclusions about the benefits of democratization for women. For instance, during the transition to a global market economy and democracy in former Soviet countries, relative to men, women's employment declined substantially (Wejnert, 2002), as did their rate of inclusion in politics. For example, by the late 1990s, women's unemployment skyrocketed to 60-70 percent in Russia and the Ukraine, while the rate for men was also high but reached on average 40-50 percent (Zherebkina 2000). Such high women's unemployment rate constrasted sharply with the communist period when the female employment level was one of the highest in the world (Bodrova \& Anker 1985). The disadvantaged position of women in the labor market was further amplified by gender wage inequality (on average, women earned 60 percent of men's wages). In some of the former Soviet countries, a decline in the provision of women's health care, especially medical assistance at birth, led to an alarming increase in maternal mortality (Wejnert and Djumabaeva 2004; Wejnert, Steimetz and Prakash, 2013).

Similar processes are being observed in currently democratizing West Africa, where the interplay between gender relations, democratization, and economic empowerment of women (e.g., via microfinance) is challenged by persistent economic crisis and a dominant patriarchal ideology in gender relations (Belanger, 2012). Particularly, the demise of domestic manufacturing (an economic domain in which women are particularly involved), the decline in the practicality of small farms and rural areas, and the privatization of some of the governmental institutions that are vital to women's employment and services has had a particularly negative impact on women in West Africa (Belanger, 2012).

Consequently, it is quite possible that the beneficial effects of democratization and global market economic development (popularly known as globalization or globalized development) are not uniformly equal, nor occur temporally at the same rate, in all groups within a society. Indeed, across countries, women who have more complex societal roles than men and whose employment is more tenuous, are more vulnerable to the rapid restructuring in macropolitical and economic systems and bear more of the costs of politico-economic changes (Walsh 2012, Waylen 2007). Thus, several scholar demonstrate that across countries, the effects of globalization and democratization on men are positive concerning education and economic 
opportunities, however, women experience several challenges (e.g., Beneria 2003, Fallon, Swiss, and Viterna 2012; Seguino, 2000). These include a decline of women's labor force as a function of democratic growth and the ratio of girls to boys in elementary and secondary schools (Wejnert 2015: 14-15). And as research show, low schooling for girls means slower growth for all (Klasen, 2002:346). Plausibly, the indicated decrease in women's labor force participation leads to a decline in women's decision-making power within families causing a lower enrolment of female children in schoolsan assumption in accord with Coleman (2004) and other studies (Luz and Agadjanian 2015; Shahidul, 2013). Morever, some studies indicates that the economic and social equality of gender is often absent in emerging democracies. For example, over time, female life expectancy declines with an increase in democracy in lower developed countries, a seeming contradiction to the popular assumption about postivie effects of democracy (Wejnert 2015: 14-15), and the emerging democratic regimes co-opt the voice of women and absorb gender issues into their agendas suppressing demands for women's empowerment, like in Latin America and South Africa (Walsh 2012).

In sum, the effects of democratization and globalization on men and women across countries vary and while democratization and globalization leads to an increase in men's education and labor force participation, women's educational attainment, labor force participation and life expectancy are often challenged. Why, then, is democratization and economic globalization not as beneficial to women as to men despite feminist scholars' postulates that democracy, and modern, global development entail the enhancement of women's social status and position?

Regardless of substantial importance, critical review of studies on differential effects of worldwide democratization and a globalized, neoliberal economy as a function of gender are rarely available. Such paucity stems in part from limited research on effects of political and economic processes on women (few exceptions are studies by Fallon, Swiss and Viterna 2012, Viterna and Fallon 2008, Paxton et al. 2006, Walsh 2012 and Wejnert 2015). Nevertheless, the theoretical explanations seem necessary given the complexity of the interaction of democratization and global development in and of themselves, and the potential differential outcomes of these processes as a function of gender.

This study builds on the work of world polity (e.g., Fallon et al. 2012; Paxton et al. 2006; Przeworski et al. 2000; Welsh 2012), and global market economic development (e.g., Beneria \& Bisnath, 2004; Beneria, Berik and Floro, 2016; Harvey 2005; Kabeer 2005; Kingfisher 2002). It integrates models of political and economic processes to uncover several mechanisms that could lead to positive outcomes for women from democracy and globalization but fall short of actual women's empowerment. This critical review and resultant conceptual framework are subsequently used to develop a conceptual model of women's empowerment and to explain why benefits of democracy and globalized development are not equally distributed across gender, i.e., why democracy is gendered.

\section{MAJOR PROCESSES EFFECTING WOMEN'S EMPOWERMENT GLOBALLY}

Two major components that refer to outcomes of a) democracy and b) globalization group political and economic variables to create the integrative conceptual framework of women's empowerment. Each component offers a different lens for understanding how variables o democracy and globalization influence women's empowerment and gender equality. The first of these components is associated with variables of democracy, which encompasses two sets of variables-women's movements and legislative representation, and each of these sets of variables is associated with sub-variables described in the text that incorporate women's opportunities to impact laws, policies, and 
practices aimed at women's empowerment. The second component involves characteristics of the global market economic system, i.e., variables of globalization and incorporates three sets of variables that influence women's probability of empowerment and incorporate processes that modulate outcomes of globalization via structural characteristics of the modern market economy. Taken together in an interactive, heuristics manner, variables of democratization and globalization determine the probability of whether indicators of democracy and the assistance of globalized development empower women. Subsequently, the political and economic infleunces are altered by the characteritics of the women per se as important contributors to the empowerment process. The conceptual framework of women's empowerment combines sets of variables of democratization and the assistance of global market economy to determine a country's overall estimate of the probability of an adoption of policies that empower women.

1. Effects of Democratization: Women's Political Engagement

- Women's movements

a) Movements' strategies (outsider tactics, partial engagement and insider tactics)

b) Movements' solidarity (international, national)

c) Foreign aid

d) Global milestone events

- Legislative representation

a) Election

b) Gender quota

2. Effects of Globalization: a Global Market Economy

- Neoliberal principles

- Economic disfranchisement

- Welfare benefits

3. Effects of Women's Characteristics

\section{Effects of Democratization}

The effects of democratization are mainly expressed by women's political engagements that have led to enormous changes in women's status, rights and women's empowerment across the modern world. These changes were brought through two main pathways 1) the emergence of women's movement frequently assisted by a formation of gender-oriented organizations, and 2) the women legislative representation either via election or by gender quota.

\section{Women's movements}

Starting with the women's suffrage in Western democracies in the early twentieth century until the most recent women's movements that have spread across the developing world, women have been able to secure the right to vote and ask for a broad range of social and political benefits using strategies associated with movements (Beckwitz, 2007). At the same time, countries have responded to women's demands by granting women's rights, implementing support for women's policies and legislation (Coleman, 2004, Coleman and Wittes 2008), and advocating gender equality that has led to the feminization of states (Viterna and Fallon, 2008). In Africa, burgeoning women's power and political engagement secured the largest number of women's parliamentary seats in the world (Tripp, Casimiro, Kwesiga and Mungwa, 2014), while in Canada, Mexico, and the United States women's political engagement led to the establishment of gender oriented policies (Bayes and Hawkesworth, 2014). However, as studies demonstrate, the success of a women's movement depends on several factors, including a) the movement's strategies, b) the movement's solidarity and coalition building, c) the impact of foreign aid, and d) milestone global events that propagate feminist goals.

Movements' Strategies. The most successful strategies employed by women's movements are (i) "outsider tactics", which are defined as the grassroots mobilization of women and men who press political institutions to establish and comply with gender policies; (ii) partial engagement of movement activists with the state by lobbying with legislators and policy makers to establish gender equality; (iii) "insider strategies", which engender good governance by increasing the number of women in elective and appointive governmental offices; and (iv) any 
combination of the above (Bayes and Hawkesworth, 2014). Women's movements select strategies based on their longevity, historical legacy, and quality of democracy. In well-established democracies, such as the United States, Canada, and Mexico, movements use "insider strategies" or partial engagement with the state and compromise with other contesting social forces to achieve goals (Bayes, Begne, Gonzalez, Harder, Hawkesworth and Macdonald, 2006; Rueschmeyer, 2008). In low level democracies or non-democracies, women's movements use either "insider strategies," whenever a movement is organized by the social elite, or "outsider tactics" whenever a movement is formed on a strong platform of grassroots activism. For example, in Jordan, where most of the official and voluntary women's organizations have been established and led by women from the social elite, such as Queen Noor Al Hussain, Princess Basma Bint Talal, and the wives of the prime ministers, ministers, and senior officials, movement leaders use "insider strategies" and demand progressive gender reforms (Salameh 2016). In contrast, the grassroots feminist activists in Africa react to spreading international norms sympathetic to women's empowerment by insisting that governments incorporate gender equality in national policies-an" outsider tactic" (Tripp et al., 2014).

Movements' Solidarity. It is important to note that both insider strategies and outsider tactics are more successful when local women's movement is in solidarity both a) internationally with a global women's movement and $b$ ) nationally across social strata and movements within each country. Subsequently, since the early twenty's century, the cross-national solidarity of suffragist movements have led to the establishment of women's voting rights in

\footnotetext{
${ }^{1}$ Such claim is disputed by other scholars, showing drawbacks of studies that largely relied on sources available in English and thus considering only a fraction of the sources and literature available for the specific national histories of women's political
}

Europe (Rubio-Martin 2014). As some scholars claim, the European suffrage movement was also associated with movements outside of Europe, and it started in the periphery (in Pitcairn Island and New Zealand) before moving to Europe and Western world (Markoff, 2003). ${ }^{1}$ The international collaboration and contacts add momentum, strength, and legitimacy to the feminist agenda, which accelerates gender reforms. Unsurprisingly, women's activists work in alliances that model their activities on examples and accomplishments of successful movements (Tripp, et al., 2014). Across most countries in the world, as Paxton et al. (2006) demonstrate, international support is essential to women's suffrage and is vital for the election of the first women parliamentarians and the acquisition of 30 percent of a country's national legislature by women. Cross-national solidarity also stimulates the establishment of political organizations open to women's membership including one of the most progressive progender organizations, the Pan-African Parliament of the African Union led by Gertrude Mongella of Tanzania, in which half of the parliamentarians are women (Tripp et al., 2014: 1-24).

Similar to the international solidarity, the national unity augments the success of women's movements. Thus, the unity of Spanish NGO's that represented women's movement exposed and publicized concerns affecting Spanish women, including the burden of austerity measures that has been particularly harmful to women, persisting gender-based violence and limited gender equality in politics. United Spanish NGOs delivered these concerns to the Spanish government (Women's International League for Peace and Freedom, 2015). Similarly, Indonesian women's movement to create the sense of Indonesian womanhood has defined

rights. The outcome could be misunderstanding, particularly regarding the complicated history of women's suffrage in the Austrian half of the Habsburg Empire (Adams 2014). Not all scholars, however, support this dispute (Bader-Zaar 2015). 
itself as peacemaker and fighter for liberation, simultaneously promoting issues of women's rights, such as banning polygamy, forced marriage, and Bali's tourism associated with sexual exploitation of women (Martyn 2005: 167-179). Thus, to increase success, women's movements shift alliances between different social groups (Kadivar 2013) and include nonfeminist activists, political parties, civic organizations and non-state institutions (Viterna and Fallon, 2008). In contrast, limited solidarity deters the success of movements and the implementation of gender policies, e.g., the case of South African women's movement (Hassim 2006).

Foreign Aid. The success of women's movement is also modified by the support of foreign aid that helps to spread movements' agenda, legitimizes goals, and propagates policies that advance gender equality, thereby overcoming the inherent masculinity of states (Brush, 2003; Fallon, 2010; Waylen, 1998). ${ }^{2}$ For instance, in a vacuum created by the absence of women's organizations in Africa, it was the grassroots feminist movements that gained access to the international aid aimed at improving good governance. According to Tripp et al., (2014) "...with a generally positive political climate brought on by the end of war and conflict, and redrawn national constitutions that included multiparty systems and incorporated women as members of governments, the ability to deploy available resources of international aid in a way that advanced women led to much greater gender equality across many African countries" (p. 13). As a result, female-friendly policies often are established out of a desire to be seen as compliant with donor objectives (Dollar and Kraay, 2000)).

There are, however, conditions in which foreign aid does not advance women. In contrast to the

\footnotetext{
${ }^{2}$ In 1997 the IMF adopted a policy of "...a more proactive approach in advocating policies and the development of institutions and administrative systems that eliminate the opportunity for bribery,
}

early stages of democratic transition that facilitate the global diffusion of pro-women policies, international donors dictate the conditions for women's empowerment in the aftermath of democratic transition, thus stiffening local innovations in activism (Viterna and Fallon, 2008). Pressure from international institutions limits the ability of local women to assert their position when programs proposed by international agencies unintentionally reinforce patriarchal power relations and traditional gender roles as was the case in Afghanistan and Kosovo (Eifler and Seifut, 2009).

Global Milestone Events. By-and-large, foreign aid has a positive effect on the increase of women's well-being, particularly during the occurrence of milestone global events that shift the attention of world polity towards women's empowerment and substantiate the pro-women agenda. Among these international landmarklike events are the $1^{\text {st }}$ United Nations World Conference on Women in Mexico City in 1975, the United Nations Convention on Elimination of All Forms of Discrimination against Women (CEDAW) that was signed and ratified by almost all independent countries, and the $4^{\text {th }}$ World Conference on Women in Beijing in 1995 that proposed an equal proportion of men and women in national legislatures and openly called for the greater inclusion of women in politics (Paxton et al., 2006; Ramirez, Soysal and Shanahan, 1997). These milestone events particularly impact countries that are open to new policies and where mobilized women can support female candidates, create forums for political lobbying, and run supportive media campaigns for decision makers with feminist agendas who vie for positions in their country's legislature (Bayes, et al., 2006; Tripp et al., 2014). In less open societies, global events have had a limited effect on the success of women's movements as was the case in some of the

corruption, and fraudulent activity in the management of public resources" (IMF, 1997). A similar approach was adapted by institutions of international aid. 
democratizing post-Soviet countries (Saurer, Lanzinger and Frysak, 2006).

Women's Legislative Representation

The second factor affecting women's political engagement and the impact of women on the establishment of gender policies is women's legislative representation, either via a) elections or b) gender quota. By definition, democracy leads to an "increase of conformity between state behavior and citizens expressed demands" (Tilly, 2007: 140) and an opening of dialog and trust between government and citizens. An increase in democratization should lead to a higher representation of women in the legislatures of their countries (Dahl, 2000: 31) and, as some scholars argue, women representation in governing bodies have a stronger impact on women's empowerment than the impact of social movements (Hawkesworth, Harder, and Bayes, 2006). Nonetheless, a rise in the number of women in political institutions depends on (i) elections that are determined by the quality of democracy, and (ii) the adoption of a gender quota.

Elections. Quality of democracy, defined by multivariate measures of social equality, social diversity in public offices, rule of law, the competitiveness of an electoral system, and competent political parties, alters the likelihood of the election of women as legislative representatives-the higher the quality of democracy, the higher the chance for women to be elected (Diamond and Morlino, 2005). In particular, the completeness of political transition, i.e., the complete replacement of old regimes by new democratic leaderships, permits women to enter legislatures since new regimes do not hold preconceived gender discriminatory biases (Viterna and Fallon, 2008). However, in regimes that are in the process of democratic transition, leading institutions in the public sphere, civil society, and the media are rarely open to women, and women's participation in the legislature doesn't advance (Paxton and Kunovich, 2003). In these regimes, the process of democratization itself is guided by a country's pre-democratization legacy and historical experience with elections (i.e., multiple elections) (Fallon, Swiss and Viterna, 2012). As explained by Walsh (2012), when regimes are in the process of transition to democracy, the effects of democratization follow a curvilinear trend starting with an initial drop in women's legislative representation during the institutionalization of democracy followed by an increase in representation when countries gain electoral experience. The downward trend results from a shift in support for women observed after the initiation of democracy. Democratizing regimes that initially supported women's issues co-opt the voice of women, thereby lessening the power of women's demands. For example, during this turning point in South Africa, tribal leaders glorified women's domestic roles, political parties of demcoratizing Chile suppressed women's demands by absorbing women's issues into their agendas (Walsh 2012), and leaders of democratizing Poland ban abortion, promote procreation and asked women to return to domestic duties (Wejnert 2002). Often, non-democratic leaders sidestep the democratizing of leadership by incorporating women as legislative representatives and giving nominal power to women to create the impression of being modern and developing a modern society. Such strategy helps the non-democratic leaders to gain political advantage in elections but diminishes the de facto significance of women's political representation (Tripp, et al., 2014: 13), as was illustrated by policies of the President Alberto Fujimore in Peru in 1997 (Town, 2004) and leadership of President Pinochet of Chile (Walsh 2012).

Gender Quota. The effect of the gender quota, another key element influencing the efficacy of women's political power, is also conditioned by political factors. When at least one third of governmental positions are offered to womenthe "gender quota"-more policies focusing on the improvement of women's well-being are likely to pass (Jones 1998). Thus, in India, the inclusion of women into one-third of the panchayats (local councils) enabled the councils 
to elect women as political leaders (Bertrand, Duflo \& Mullainathan, 2002). Subsequently, women-led councils in India completed 62 percent more drinking water projects than panchayats led by males (United Nations Women 2015). Also, in Norway, the presence of women in municipal councils increased childcare coverage (United Nations Women 2015). It is not surprising that women legislators actively work on an increase in women's representation in politics (Carr 2008). In established western democracies, women legislators concentrate on women winning presidential elections and on breaking the male control of governments (Jaquette 2009), while in fledging African democracies women legislators concentrate on passing gender quotas (Tripp et al., 2014).

Importantly, however, according to Paxton et al., (2008), democracy may have a positive impact on suffrage but not on the number of women in parliaments and many non-democratic regimes have a higher women's legislative representation than democracies. Therefore, the effectiveness of gender quotas varies highly and is a function of several factors including international pressure (gender quotas were only mildly successful prior to the Beijing conference) (Paxton et al. 2008), local culture such as the masculine cultures found in Latin America (Jaquete 2009), and the position of women in the social strata, such as an overall low position of women in India (Gibson, 2012). Consequently, despite the introduction of a gender quota, Mexico lags behind Canada with a smaller number of women in local and national governments, unequal employment, discriminatory employment due to pregnancy, limited access to health care, and higher levels of gender violence (Hawkesworth, Harder, and Bayes, 2006: 183). Also, gender quotas do not

\footnotetext{
${ }^{3}$ Gender Empowerment Measure (GEM) was created by the United Nations Development Program to capture gender disparities in "women's participation in political decision-making, their access to professional opportunities and their earning power" (UNDP 1995:72).
}

secure de facto political power for women in scheduled tribes (the socially disadvantaged casts) in India. Despite holding one third of the seats in such governments, the only power these women hold is a redistributive power, specifically, direct access to the redistribution of public good (e.g., housing and latrines) but not to decision making in the local governing institutions (Gibson, 2012). Similarly, prevalent "gender quotas" in the municipal and central governments of the former and current communist states have not empowered women as much as the Swedish women are empowered without a gender quota. Russia, which endorses a gender quota, scored 0.0 (on a scale of 0.0 to 1.0) on the index of Gender Empowerment Measure (GEM). ${ }^{3}$ It is the lowest score in Europe and contrasts with the score of 1.0 found in equalitarian countries such as Norway and Sweden.

Thus, although many scholars consider the electoral system and political institutions to be detrimental to women's political power (Waylen 2007), gender quotas often advance women de jure but not de facto. ${ }^{4}$ Especially, as argued by Fallon et al. (2012), in developing countries gender quotas do little to modify the curvilinear (initially negative and later positive) outcomes of democratization on women's representation in legislatures and women's rights, and the limited impact of gender quotas does not change even when feminist groups frame gender quotas as symbols of modernity and those supporting gender quotas as being modern.

In sum, regardless of the belief that political and cultural factors, rather than socioeconomic factors, are the main contributors to women's parliamentary presence (Inglehart, Norris and Welzel, 2002) and that freedom of expression of citizens' political preferences is a

\footnotetext{
${ }^{4}$ According to the feminist definition of democratic equality, both spheres, de jure and de facto equality of women should be present to account for gender equality.
} 
major determinant of the provision of social welfare in democracies (Brook and Manza, 2007), neither the representation of women in legislatures nor gender quotas guarantee sufficient outcomes in democracies to increase women's empowerment so that it is on par with men (Vullnetari and King, 2011). Gender inequality could be especially problematic for new democracies in developing countries that are economically volatile, politically unstable, and are in the process of social, economic and political transitions. Not surprisingly, while analyzing women's political engagement in democracies, Fallon et al. (2012) found that "democracy operates differently in the context of developing countries" (p. 383). The uncertain effect of women's legislative representation on the increase of women's empowerment poses questions as to whether the interaction of democracy and the global market economy could shed more light on this issue.

\section{Effects of Globalization}

Since the 1970s, the global market economy also referred to as economic globalization, is considered to be a route to modern development and one of the most favorable precursors for the establishment of democratic institutions (Dahl, 2000). It focuses on curing the weak economies while simultaneously increasing the well-being of citizens across all social strata (Harvey, 2005:

88). Indeed, during the globalization era, since the 1970s through 2002, across the world, infant mortality rates decreased by almost half, adult literacy increased more than a third, primary school enrollment rose, the average life span increased by 11 years in low-developed countries, and looking forward, through 2025 worldwide life expectancy is projected to rise from 62 years to 68 years in less developed countries (United Nations Development Program, 2005). At the same time, the development of the global market economy leads to greatly increased inequality within states, and the social inequality is predicted to increase over time (Bourquiquon, 2016).Simultaneously, the power of disenfranchised social groups is predicted to weaken (Inglehart, 2016). Regardless of its expected potential, market economic growth has led to a substantial increase in social inequalities within countries, with the richest segments of societies gaining the biggest portion of resources and using economic power to shape politics in their favor, e.g., states reduce welfare support and decrease expenditure on state infrastructures like schools and roads to accelerate economic growth (Harvey, 2005). On the global scale, the most economically powerful countries can have a greater influence on global trade and finances, obtaining greater assets at the expense of others.

Growing social inequality particularly affects women because they are mothers and employees, and states support women's employment but not occupational achievement (Mandel and Semyonov 2006). Also, the globally prevalent gender gap in salaries adds to gender inequality. Therefore, regarding women, three factors illustrate the impact globalization a) neoliberal principles, b) economic disfranchisement of women, and c) effects on welfare benefits.

Neoliberal Principles. Neoliberal economy proposes that "human well-being can best be advanced by liberating individual entrepreneurial freedoms and skills within an institutional framework characterized by strong private property rights, free markets, and free trade" (Harvey, 2005: 88). In developed countries, the global economy is intended to increase overall economic growth (e.g., by lowering inflation and interest rates) and in developing countries, it is supposed to cause state welfare expansion, thus improving citizens' well-being (Brady, Beckfield, and Seeleib-Kaiser, 2005). Consequently, democratizing countries are often "pressed" by foreign donors or networks of well-established democracies to adopt global market economy as a prerequisite for foreign aid or inclusion into global economic and political pacts. 
Regardless of its benefits, entrance into the neoliberal global economy leads to many unexpected negative consequences. Rapid economic growth leads to a substantial increase in social inequalities within countries, with the less privileged segments of societies gaining the smaller portion of resources. According to comparative analyses conducted by United Nations Development Program, the social inequality that results from the market economy impacts the security and status of women's employment, lower women's earning power and disfranchise women economically (UNDP 1995: 72). With the expansion of social and gender inequality "in Latin America, where the first wave of forced neo-liberalization struck in the early 1980s, the result was, for the most part, a whole 'lost decade' of economic stagnation and political turmoil” (Harvey 2005: 88).

Economic Disfranchisement of Women. Considering increasing social inequality, Sequino (2000) argues that neoliberal economies use gender wage inequality to increase profit. The author claims that "inequality born by women appears to have a positive effect because this condition stimulates exports and raises profit expectations" (Sequino 2000: 1222) and in lowdeveloped countries, the global economy leads to a surge of newly created jobs for women but these jobs are low-paid and tenuous. Democratizing and globalizing countries that are middle-economies, on the other hand, to stimulate economic growth and reduce unemployment, encourage female employees to forgo employment and return to domestic duties, e.g., semi-economicaly developed, postcommunist democracies in the 1990s (Wejnert 2002).

Not surprisingly, a study by Tzannatos (1999) on women and the labor market in the market economies of democratic countries concludes

\footnotetext{
${ }^{5}$ In non-democratic states the conditions can be worse as in China where, in addition to much lower wages and higher job insecurity, personnel cutbacks are used to increase efficiency and more women
}

that "market-based development alone can be a weak instrument for reducing inequality between the sexes" (p. 551). The negative impact of the global market economy on social equalities, the escalation of poverty, and an increase in women's disfranchisement contrast sharply with the democratic principle of equality. It also contradicts a claim that "the market economy proves attractive precisely because it is more conducive to individual self-realization than a society controlled the moral economy or largely regulated command economy" (Bratton, Matters and Boardi, 2004). Hence, Walker (2006) responds that democratization and market liberalization do not have to complement each other and, indeed, only a small portion of Democrats favor market reforms in the United States. In summary, in both democratic and nondemocratic state, the economic well-being of women is compromised by a neoliberal economic system (McKinnon, B, S. Harper, J. Kaufman and Y. Bergevin, 2014). ${ }^{5}$ Women are worse-off, however, in poor, non-democratic countries with a rightist ideology, for example, women are worse-off in not democratic Haiti than in the democratic Dominican Republic than is located on the same island and is economicaly similar (Moon and Dixon, 1985).

Welfare Benefits. Increasing social inequality influence strongly women's social position because women have a greater variety of social roles, the dual role of being producers and mothers, more tenuous employment status than men and lower salaries than men. Therefore, during democratization and the spread of the global market economy, women face several problems that are unique (Kingfisher, 2002; Stycos, Wejnert and Tyszka 2002, Wejnert and Djumabaeva, 2004). As studies indicate, in addition to the general difficulties stemming from rollbacks of state benefits, women experience new difficulties that reflect the

than men are losing jobs. According to Wu (2014: $p$. 44), "Women benefitted most from the former planned economy". 
elimination of benefits specific to women. Additional challenges include (a) cutbacks to women's benefits by employers, (b) reductions in welfare programs oriented towards mothers and children, (c) lower job security, and (d) lower wages than men (Kingfisher, 2002; Seguino, 2000; Wejnert, Steimetz \& Prakash, 2013). For example, the negative effects of the market economy on women's welfare benefits was visible in well-established democracies in the 1980s. To achieve rapid economic growth, Canada, New Zealand, Australia, Great Britain and the United States cut welfare expenditures and boosted the involvement of states or provinces in social benefits moving the responsibility of basic protection and care from the national government to individuals and families. Those most strongly affected by these reforms were already economically and politically disenfranchised-poor mothers with young children (Kingfisher, 2002: 32-49). Since the 1990s in post-communist democracies that embraced the global market economy, an abundance of consumer products became available that eliminates the hours-long waiting time to purchase basic goods, thus saving women's time. Yet, unemployment among women is also disproportionally high, women lost most benefits that were common in communism, and private industry is less interested in providing maternal benefits. Maternity leave, job tenure, paid child-sick leave, day-care facilities on company premises or paid vacation leave ceased to exist in all but state-run companies (Fuszera 1994, Wejnert, Parrot and Djumabaeva, 2008). And in Kyrgyzstan, the democratizing, post-communist Asian country, the state government shifted limited economic resources away from maternal health and closed regional maternity units which resulted in a rapid increase in maternal mortality (Wejnert, Parrot and Djumabaeva, 2008).

Although democracies have the vitality to reverse the negative trend of growing inequality because democratic representation and direct pressure from social groups and individuals from outside of state bureaucracy can lead to welfare provisions (Moore and Dixon, 1985), yet, democracy in itself is not sufficient for achieving an equal society. Rather, it "depends on what the mass electorate does with the franchise" (Hewitt, 1977: 451). As discussed in a prior section, women limited social and political power and limited representation in legislatures may not be sufficient to overturn embedded structural gender inequalities in global market economies across the world's societies.

\section{Effects of Women's Characteristics}

Additionally, the attributes of women, per se, are important contributors to the empowerment process. Of course, as noted above, women interact within the larger societal context and the contextual influences most likely to interact with the political and economic milieu include social movements, gender quotas, women's representation in the legislature, and neoliberalism, education and employment opportunities. Nonetheless, women's characteristics involve factors that determine the perception of the value of empowerment and the actual feasibility to pursue or demand empowerment equal to men. Among such characteristics are women's status, personal characteristics, and behaviors. Women's characteristics play a salient role in modulating the impact of a country's political and economic system and directly influence processes of political decision making about whether to adopt policies, and to what extent those policies are ratified, that secure equality between sexes. Consequently, women's characteristics, together with political and economic factors, contribute to a country's threshold of adoption of actions or policies that could empower women.

The emphasis on women's characteritics is wellarticulated by Mahvish Farooq (2015), who discusses the effects of the empowerment behavior of women on women's employment (e.g., control of their life, social mobility, and freedom of movement). In addition, the 2015 victory of Mrs. Ellen Johnson Sirleaf in the Liberian presidential election illustrates well the 
significance of the characteristrics of the women, per se, on women's empowerment. Mrs. Sirleaf, the first African female president, was elected President mainy due to a high turnout of women voters (close to 80 percent of Liberian women went to the polls during this first post-war election), the assertiveness and perseverance of Liberian market women, women's unity and strength of character, and the widespread determination of women to elect a female president (Cooper, 2017).

The importance of women's characteristics is most critically observed when considering the temporal rate of women's empowerment. Given equal exposure to information about gender empowerment and equal contextual influences, no other variable than the variation in time to empowerment--the very essence of the temporality of empowerment--so strongly suggests the contributory role of the characteristics of woman in women's empowerment.

\section{CONCEPTUAL MODELING OF WOMEN'S EMPOWERMENT}

Women's empowerment correlates with the larger societal context, where, among the contextual influences most likely to impact women's empowerment, there are characteristics of democratization that determine women's opportunity to form laws and policies and undertake actions aimed at women's empowerment and characteristics of the global market economic system (globalization) that affect the probability of women's empowerment. The influences of democratization refer to women's movements and legislative representation and involve: the solidarity and network connectedness of women's movements, foreign aid promoting gender equality, global support of women's equality, and the political inclusion of women. Among the influences of globalization are characteristics that alter welfare benefits and modulate outcomes of the global market economy for women, e.g., women's economic empowerment. Taken together in an interactive manner, the characteristics of democratization and globalization generate permissive conditions of women's empowerment that could to be empirically tested. Thus, empowerment of women could be measured by, for example, increase of women's education, labor force participation, parity of women's salaries, and better health. It could be also measured by the introduction of pro-gender policies that enhance the well-being, social position and decisionmaking power of women within family and community.

It is important to note that the interactive relationship between democracy and globalization provides a means of representing variables of individual countries determining women's empowerment. Thus, if value of democracy effects for any country is held constant across countries, variation in the adoption of policies that empower women would be highly dependent on a country's value of globalization effects. In any case, a country would have a characteristic threshold value that is subject to modification as a function of the changing effects of democratization, the outcomes of globalization and characteristics of women.

Consequently, such constructed conceptual framework would allow for a modeling of women's empowerment, i.e., an occasion when all the variables above can be quantified and integrated in an attempt to predict the level of women's empowerment. For women in any country, empowerment will depend on the relative values of outcomes of democratization and account for the mitigating impact of globalization effects, and a salient role of women's characteristics per se in modulating the impact of a democracy and globalization in a country.

Therefore, if there is a change in the effects of democracy, e.g. an increase in the intensity and size of women's movements that aims at women's rights, the country may adopt policies that empower women, even if the effects of 
globalization are high, which would normally deter women's empowerment. For example, as implied by Tripp et al., (2014), the strong women's movement and increase of women's legislative representation in African countries greatly contributed to women's empowerment, regardless of the introduction of the global market economy that led to closing jobs that were typically occupied by women and led to a decline of economic profit from small farm productions that mainly benefitted women. Increase of oportunities of women's political represenation-one of the outcomes of democracy, increased the probability of adoption of policies that empowered women regardless of higher level of globalization that normally would have weakened the women's position and prevent adoption of policies supporting women.

A good example provides also a comparative evaluation of pro-women policies during the American presidencies of Ronald Reagan and Barack Obama. In both periods, women's legislative representation remained relatively stable and low in the United States. However, President Obama imposed regulations to control the free market economy, while President Reagan was a strong supporter of elimination of control measures of liberal market economy. President Obama adopted policies supporting women's empowerment, e.g., free maternal health screening, an enlarged "Supplementary Nutrition Assistance Program" (SNAP) program that supported many poor women and funded planned parenthood. In contrast, President Reagan introduced several restrictions on women's empowerment: substantial cuts to welfare provisions, no free women's health screaning and restricted abortion.

\section{IMPLICATIONS FOR PRACTICES AIMED AT WOMEN'S EMPOWERMENT}

Although, scholars agree that democracy and its principle of social equality is more beneficial to women than non-democracy (e.g., Moon and Dixon, 1985), the mere introduction of a democratic system or globalization does not lead to women's empowerment. Thus, the critical review presented above and resultant conceptual framework, suggest at least three practical pathways that could protect women's economic, social, and health benefits and develop equality between sexes in democratic and embracing global market economy countries. These pathways are: a) the strengthening of women's political rights, b) promotion of awareness of global gender disparities, and c) addressing the negative effects of globalized development on women.

First, there must be a pronounced emphasis on the implementation of women's political rights-the right to vote and hold public office greatly empowers women (Avdeyeva, 2015; Metelska and Niedzielska, 1993; Paxton et al., 2012). Women's presence in governing institutions secures women's rights, protects their wellbeing, and prevents the withdrawal of resources from women during economic downturns, as well as during economic and political stability. The former situation is exemplified by the condition in newly democratizing Kyrgyzstan, where the government closed regional maternity units when faced with limited economic resources causing maternal mortality to skyrocket to the point of requiring help from the World Health Organization. At that time, women constituted only $3 \%$ of the members of the Kyrgyz Parliament, the Duma (Stephenson, 1998; Wejnert and Djumabaeva, 2004). On the other hand, there is an amazing increase in gender equality and prosperity in Uganda and South Africa, where today there are more women in politics than in most well-developed countries (Goetz, 1998). Furthermore, Rwanda ranks first in the world in the number of women representatives in the elected lower house of parliament as of 2014 (Hunt, 2014:152). All three countries, with gender inclusive policies, are rapidly developing economically. Hence, creation of inclusive political space helps to create responsive democratic governance.

Second, it is crucial to disseminate an awareness of gender disparities and disfranchisement of 
women globally and, at the same time, to promote knowledge about women's achievements and contributions to the development of countries. Through such actions traditional gender-biased practices that undo the achievements of gender mainstreaming would be circumvented. This calls for a focus on increasing public recognition of the enormous potential of the empowerment of women for the development of a country and for global development. Social equality is fundamental to global progress, prosperity, peace, and to future improvements in societal life. As Kofi Annan, Secretary-General of the United Nations noted in referring to women, "...study after study has shown that there is no effective development strategy in which women do not play a central role. When women are fully involved, the benefits can be seen immediately: families are healthier; they are better fed; their income, savings, and reinvestment go up. And what is true of families is true of communities and, eventually, of whole countries" (Annan, 2002:3). And what is true of women may be equally true of other disfranchised groups. Recognition of the impact of women and other less privileged groups on the overall development of countries could not only defray the short-term negative outcomes of democratic and market economic transitions, but also hasten the processes of consolidation of democracy and global development (e.g. Paxton et al.; Walsh, 2012; Wejnert, 2015).

Third, an emerging economic gap between social strata that results from the interaction between democracy and the global neoliberal economy may foster discrimination against women, which departs sharply from the democratic value of equal opportunity for all citizens. This seems especially true for countries that democratize while simultaneously embracing a global free market economy. Costs such as unemployment, unequal access to financial and other resources and the resulting poverty can be substantial and overshadow the positive outcomes of democracy (Bourquiquon, 2016; McKinnon et al., 2014). To aid women during countries' economic downturns, protective measures securing women's economic and social position need to be implemented.

Despite the many ways in which democracy and globalized development enhance people's wellbeing, as critical reviews show, there are several challenges to positive outcomes for women. These differing effects of democracy and the global economy to women's empowerment need to be considered as policies develop in emerging as well as established democracies.

\section{REFERENCES}

Adams, J. 2014, 'Women and the Vote: A World History', Oxford: Oxford University Press.

Annan, K. 2002, 'Speech of the Secretary-General of the United Nations at the General Assembly of the United Nations', The New York Times, accessed December $29^{\text {th }} 2017$

Avdeyeva, O. 2015, 'Defending Women's Rights in Europe', Albany, NY: State University of New York Press.

Bader-Zaar, B. 2015, 'An Attempt at a Global History of Women's Suffrage', Review of 'Women and the Vote: A World History' by Jad Adams. Humanities and Social Sciences Online.

Bayes, J., Begne, P., Gonzalez, L., Harder, L., Hawkesworth, M., Macdonald, L. 2006, 'Women, Democracy and Globalization in North America. A Comparative Study', New York: Palgrave.

Bayes, J. and Hawkesworth, M. 2006. "Introduction." In Bayes, Begne, Gonzalez, Harder, Hawkesworth and Macdonald. Eds. 2006. Women, Democracy and Globalization in North America. A Comparative Study. New York: Palgrave.

Bayes, J. and Hawkesworth, M. 2014, Gender, Globalization, and Democratization', Rowman and Littlefield, USA.

Beckwith, K. 2007, 'Mapping Strategic Engagements. Women's Movements and the State', International Feminist Journal of Politics, vol. 9, no. 3, pp. 312-338. Beer, C. 2009, 'Democracy and Gender Equality', Comparative International Development. vol. 44, pp. 212-227.

Belanger, C. 2012, 'Women and Democratization in West Africa: The Case of Cercle d'Autopromotion pour le Developpement Durable', The Journal of Pan African Studies, vol. 4, no. 10, pp. 289-304. 
Beneria, L. 2003, 'Gender, Development, and Globalization: Economics as if All People Mattered. Routledge, New York, 272 pages; GBP 13.99.

Beneria, L. Bisnath, S. 2004, 'Global Tensions: Challenges and Opportunities in the World Economy', New York: Routledge.

Beneria, L., Gunseli, B., Maria, F. 2016, 'Gender, Development, and Globalization. Economics as if all People Mattered', 2nd edition. New York: Routledge Press.

Bertrand, M., Duflo, E., Mullainathan, S. 2002, 'How Much Should we Trust Differences-in-Differences Estimates?' Cambridge, MA: National Bureau of Economic Research.

Bloom, S. S., Wypij, D. and Gupta, M. D. 2001, 'Dimension of women autonomy and influence on maternal health care utilization in North India City'.

Demography, vol. 38, no. 1, pp. 67-78.

Bodrova, V. and Richard, A. 1985, 'Working Women in Socialist Countries: The Fertility Connection'. Geneva: International Labor Office.

Bourguignon, F., 2016, 'Inequality and Globalization', Foreign Affairs, vol. 95, no. 1, pp. 11-15.

Brady, D., Beckfield, J., Seeleib-Kaiser, M. 2005, 'Economic Globalization and the Welfare State in Affluent Democracies, 1975-2001', American Sociological Review, vol. 70, pp. 921-948.

Bratton, M., Mattes, R., Gyimah-Boardi., E., 2004, 'Public Opinion, Democracy, and Market

Reform in Africa', New York, NY: Cambridge University Press.

Brooks,C. and Manza, J. 2007, 'Why Welfare States Persist: The Importance of Public Opinion in Democracies', Chicago, IL: University of Chicago Press. Brush, L. 2003, 'Gender and Governance', Walnut Creek, CA: Altamira Press.

Carr, D. 2008, 'Gender Politics', Context, Fall, pp. 5859.

Chattopadhyay, R. and Duflo, E. 2004, 'Women as Policy Makers: Evidence from a Randomized Policy Experiment in India', Econometrica, vol. 72, no. 5, pp. 1409-1443.

Coleman, I. 2004, 'The Payoff from Women's Rights', Foreign Affairs, vol.83, pp.80-95.

Coleman, I. and Wittes, C,T. 2008, 'Economic and Political Development of the Middle East. In

the Saban Center at Brookings and the Council on Foreign Relations, Restoring the Balance. A

Middle East Strategy for the Next President. Washington, DC: Brookings Institution Press.

Cooper, H. 2017, 'How Women Delivered Africa's First Female President', New York Times,

March, vol. 6, A8.
Dahl, R. 2000, 'On Democracy', New Haven: Yale University Press.

Diamond, L. and Morlino, L. 2005, 'Assessing the Quality of Democracy', Baltimore, MD. John Hopkins University Press.

Dollar, D. and Kraay, A. 2000, 'Property Rights, Political Rights, and the Development of Poor

Countries in the Post-Colonial Period', World Bank Working Papers. Development Research

Group, pp.1-50.

Eifler, C. and Seifert, R. 2009, 'Gender Dynamics and Post-Conflict Reconstruction', New

York, NY: Peter Lang.

Fallon, KM. 2003, 'Transforming Women's Citizenship Rights within an Emerging Democratic State: The Case of Ghana', Gender \& Society, vol. 17, no. 4, pp. 525 543.

Fallon, K.M 2010, 'Democracy and the Rise of Women's Movement in Sub-Saharan Africa', John Hopkins University Press.

Fallon, K., Swiss, L., Viterna, J., 2012, 'Resolving the Democracy Paradox: Democratization

and Women's Legislative Representation in Developing Nations, 1975 to 2009', American Sociological Review, vol.77, no.3, pp.380-408.

Farooq, M. 2015, 'Impact of Women Employment on Empowerment Behavior: A Case Study

Of Rawalakot Azad Kashmir, Pakistan', Science International, vol.27, no. 4, pp. 3811-3816.

Funk, N. and Mueller, M. 1993, 'Gender Politics in PostCommunism. New York: Routledge.

Fuszera, Malgorzata. 1994. "Market Economy and Consumer Rights: The Impact on Women's

Everyday Lives and Employment', Economic and Industrial Democracy. vol.15, pp.75-87.

Gakidou, E., Cowling, K., Lozano, R., Murray, CJ. 2010, 'Increased educational attainment and its effect on child mortality in 175 countries between 1970 and 2009: a systematic analysis', Lancet, vol. 376, no. 9745, pp.959-974.

Garrett E. 2004, 'Democracy in the Wake of the California Recall', University of Pennsylvania Law Review, vol. 152.

Gibson, C. 2012, 'Making Redistributive Direct Democracy Matter: Development and Women's Participation in the Gram Sabhas of Kerala, India', American Sociological Review.

vol. 77, no.3, pp. 409-434.

Goetz, M.A. 1998, 'Women in Politics \&Gender Equity in Policy: South Africa \&Uganda', Review of African Political Economy, vol. 25, no.76, pp.241-262. 
Hassim, S. 2006, 'Women's Organizations and Democracy in South Africa', Contesting Authority. University of Wisconsin Press.

Harris-White, B. 1996, 'A Political Economy of Agricultural Markets In South India: Masters Of The Countryside', Thousand Oaks, California: Sage Publishers.

Harvey, D. 2005, 'A Brief History of Neoliberalism', Oxford, UK: Oxford University Press.

Hawkesworth and Macdonald 2006, 'Women, Democracy and Globalization in North America. A Comparative Study'. New York: Palgrave, pp.173-189.

Hewitt, C. 1977, 'The Effect of Political Democracy and Social Democracy on Equality in

Industrial Societies', American Sociological Review, vol.42, pp.450-64.

Hill, A., \& King, E. 1995), 'Women's Education and

Economic Well-being', Feminist Economics, vol. 1, no.

2, pp. 1-26.

Hunt, S. 2014, 'The Rise of Rwanda's Women.

Rebuilding and Reuniting a Nation', Foreign

Affairs May/June, pp.150-156.

Inglehart, R. 2016, 'Inequality and Modernization', Foreign Affairs 95.1, Jan/Feb 2016, pp.2

10.

Inglehart, R. 2016, 'How Much Should We Worry', Journal of Democracy, vol.22, no.3, pp.18-23.

Inglehart, R,, Pippa N., and Welzel C. 2002, 'Gender Equality and Democracy', Comparative Sociology, vol. 1, no.3-4, pp.321-45.

International Monetary Funds. 1997. Good Governance. The IMF's Role. International Monetary Fund: Washington, D.C. U.S.A.

Jaquette, J. 2009, 'Feminist Agendas and Democracy in Latin America. Duke University Press.

Joffe, J. 2009, 'The default power: The false prophecy of US decline', Foreign Affairs, vol. 88, no. 5, pp.21-

36.

Jones, M P. 1998, 'Gender Quotas, Electoral Laws, and the Election of Women: Lessons from the Argentine

Provinces', Comparative Political Studies, vol. 31, no.

1, pp. 3-21.

Kabeer, N. 2005. 'Gender equality and women's empowerment: A critical analysis of the third millennium development goal', Gender and Development, vol.13, no.1, pp.13-24.

Kadivar, A.M. 2013, 'Alliances and Perception Profiles in the Iranian Reform Movement, 1997

to 2005', American Sociological Review, vol.78, no.6, pp.1063-1086.

Kapstein EB and Converse N. 2008, 'Why democracies fail', Journal of Democracy, vol. 19, no. 4, pp. 57-68
Kingfisher, C. 2002, 'Welfare States in Decline. Globalization and Women's Poverty', Philadelphia, PA: University of Pennsylvania Press. Klasen, S. 2002, 'Low Schooling for Girls, Slower Growth for all? Cross-coutnry evidence on the Effect of Gender Inequality in Education on Economic Development', The World Bank Review, vol.16, no.3, pp.345-373.

Lederer, IJ. (Ed.). 1992,' Western Approaches to Easter Europe'. New York: Council on Foreign Relations Press.

Lipset, S. M. 1960, 'Some social requisites of democracy: Economic development and political legitimacy', American Political Science Review, vol. 54, pp.69-105.

Lipset, SM. 1994, 'The Social Requisites of Democracy Revisited: 1993 Presidential Address', American

Sociological Review, vol. 59, no. 1, pp. 1-22.

Luz, L. and Agadjanian, V. 2015, 'Women's DecisionMaking Autonomy and Children Schooling in Rural Mozambique', Demographic Research, vol.32, pp.775-796.

Mande, H. and Semyonov M. 2006 'A Welfare State

Paradox: State Interventions and Women's

Employment Opportunities in 22 Countries', American Journal of Sociology, vol. 111, no. 6, pp. 1910-1949

Markoff, J. 1996, 'Waves of Democracy: Social Movements and Political Change', Newbury

Park, CA: Pine Forge Press.

Markoff, J. 2003, 'Margins, Centers, and Democracy: The Paradigmatic History of Women's

Suffrage', Signs, vol.29, pp.85-116.

Martyn, E. 2005, 'The Women's Movement in Postcolonial Indonesia. Gender and Nation in a

New Democracy'. New York, Routledge.

McKinnon, B., Harper, S., Kaufman, J., Bergevin, Y., 2014, 'Socioeconomic inequality in

neonatal mortality in countries of low and middle income', The Lancet Global Health, vol.2, no.3, pp.16573.

Metelska, M. and Niedzielska, A. 1993, 'Z Wysokosci Szpilek Pani Ewy. Obrazek z kampanii Wyborczej SLD', Gazeta Wyborcza, November, vol.16, no.3.

Molina, G.G. and Purser M. 2010, 'Human Development Trends Since 1970: A Macro Story of Micro Changes', HDRO Working Paper, 01/2010.

Moon, B. and Dixon, W. 1985, 'Politics, the State, and Basic Human Need: A Cross-National

Study', American Journal of Political Science, vol.29, no.4, pp.661-694.

Murthy, R. 1996, 'Fighting female infanticide by working with midwives: An Indian case', Gender and Development, vol. 4, no. 2, pp.20-27. 
Murthy, R. 2001, 'A Note on Male Governance of South Indian Family Businesses and Its Implications for Women' ${ }^{\prime}$ Indian Journal of Gender Studies, vol.8, no.1, pp.89-96.

Pakistan Association of Anthropology, 2015, 'Impact Of Women Employment On Empowerment Behaviour: A Case Study of Rawalakot Azad Kashmir, Pakistan Islamabad', by Farooq, M. Pakistan Special Issue Sci.Int. (Lahore), vol. 27, no.4, pp.3811-3816.

Paxton, P., Hughes, M.M., Green, J., 2006, 'The International Women's Movement and

Women's Political Representation, 1893-2003', American Sociological Review, vol.71, pp.898

920.

Paxton, P. and Kunovich, S. 2003, 'Women in National Legislatures: A Cross-National Analysis', Social Forces, vol.81, no.5, pp.87-114.

Paxton, P., Green, J. and Hughes, M. 2008. Women in Parliament, 1945-2003: Cross-National Dataset.

ICPSR ed. Ann Arbor, MI: Inter-university Consortium for Political and Social Research

Przeworski, A., Alvarez, M., Cheibub,A.J., Limongi, F., 2000, 'Democracy and Development:

Political Institutions and Well-being in the World', Cambridge UK: Cambridge University Press. Przeworski A. 2010, Democracy and the Limits of SelfGovernment, Cambridge University Press

Ramirez, O.F., Soysal, Y., Shanahan, S. 1997, 'The Changing Logic of Political Citizenship: Cross

National Acquisition of Women's Suffrage Rights, 1890-1990', American Sociological Review vol.62, no.5, pp.735-45.

Rubio-Martin, R. 2014, 'The Achievement of Female Suffrage in Europe: on Women's Citizenship', International Journal of Constitutional Law, vol.12, no.1, pp.4-34.

Rueschemeyer, D. 2008, 'Democracy and Social Welfare', Contemporary Sociology: Review

Essays', vol.37, no.5, pp.407-410.

Rueschemeyer, M. 1998, 'Women in the Politics of Post-communist Eastern Europe'. New

York: Sharpe.

Salameh, M. 2016, 'Feminist Elites in Jordan: Features and Characteristics: 1989-2016', Paper presented at the World Conference on Studies on Women, Rome, October 21-22, 2016.

Saurer, E., Margareth, L., Frysak, E., 2006, 'Women's Movements: Networks and debates in

Post-communist countries in the 19th and 20th centuries. Böhlau Verlag Köln', Weimar,

Germany.

Seguino, S. 2000, 'Gender Inequality and Economic Growth: A Cross-Country Analysis', World
Development, vol.28, pp.1211-1230.

Shafer, MD. 1994, 'Winners and Losers: How Sectors Shape the Developmental Prospects of States'. Ithaca, NY: Cornell University Press.

Shahidul, S.M. 2013, 'Mothers' Participation in the family Decisions and Daughters'

Education', International Journal of Humanities and Applied Sciences, vol.2, no.1, pp.1-4.

Stephenson, P. (Ed.) 1998, 'Improving women's health services in the Russian Federation: Results of a pilot project', Washington, D.C.: World Bank

Stycos, J., Wejnert, B., Tyszka, Z., 2002, 'Polish

Women During Transition to Democracy: A

Preliminary Research Report', In Wejnert, B. Ed.

Transition to Democracy in Eastern Europe and Russia: Impact on Politics, Economy, and Culture. Westport, CT: Praeger.

Tilly,C. 2007, 'Democracy', New York: Cambridge University Press.

Town, A. 2004, 'Norms and Inequality in International Society: Global Politics of Women and the State', Dissertation Thesis, University of Minesota, Minneapolis, MN.

Tripp M.T., Casimiro, I., Kwesiga, J., Mungwa, A., 2014, 'African Women's Movements', New

York: Cambridge University Press.

Tzannatos, Z., 1999, 'Women and Labor Market Changes in the Global Economy: Growth

Helps, Inequalities Hurt and Public Policy Matters', World Development, vol.27, pp.551-569.

United Nations Development Program. 1995. Human Development Report. New York: Oxford

University Press.

United Nations Women. 2015. Facts and Figures: Economic Empowerment, $<$ http://www.unwomen.org/en/what-we-

do/leadership-and-political-

participation/factsandfigures\#notes. United Nations

Women-Headquarters, accessed April 8,

$\underline{2016>}$

United Nations Millennium Project, 2005: 47

http://www.un.org/webcast/summit2005/MDGBook. pdf

Viterna, J. and Fallon, K. 2008, 'Democratization, Women's Movements, and the Gender

Equitable States: A Framework for Comparison', American Sociological Review, vol.73, pp.668-689.

Vullnetari, J. and King, R. 2011, 'Remittance, Gender, and Development in Albania's

Society and Economy in Transition', New York, NY: I.B. Tauris Academic Studies. 
Walsh, D. 2012, 'Does the Quality of Democracy Matter for Women's Rights? Just Debate and Democratic Transition in Chile and South Africa', Comparative Political Studies, vol.45, no.11, pp.1323-1350.

Walker, E. 2006, 'Public Opinion, Democracy, and Market Reform in Africa', Contemporary

Sociology: A Journal of Reviews, vol.35, no.2, pp. 173. Waylen, G. 1998, 'Gender, Feminism and the State: An Overview', Pp.1-17 in Gender, Politics

and the State, edited by V. Randall and G. Waylen. New York: Routledge.

Waylen, G. 2007, 'Engendering Transitions: Women's Mobilization, Institutions, and Gender Outcomes', Oxford, UK: Oxford University Press.

Wejnert, B. (Ed.). 2002, 'Transition to democracy in Eastern Europe and Russia: Impact on economy, politics and culture', Westport, CT: Praeger.

Wejnert, B. 2015, 'Turning Globalization and the Diffusion of Democracy into

Opportunities for Women and Girls', Research in Political Sociology, vol. 23, pp.3-31.

Wejnert, B., Steinmetz, S., Prakash, N., 2013, 'Safe Motherhood in Globalized

World', New York: Routledge Press.

Wejnert, B. 2008, 'Effects of Global Democracy on Women's Reproductive Health: 1970

2005, Cross-World Analysis', Marriage and Family Review, vol. 22, no.2-3, pp.154-172.

Wejnert, B., Parrot, A., Djumabaeva, A. 2008, 'Maternal Health Policies

in Countries in Transitional Economies: Poland and Kyrgyzstan, 1990-2006', Marriage and

Family Review, vol. 44, no. 2-3, pp.279-300.

Wejnert, B. and Djumabaeva, A. 2004,' From Patriarchy to Egalitarianism: Parenting

Roles in Democratizing Poland and Kyrgyzstan', Marriage and Family Review, vol. 36, no.3-4,

pp.147-171.

Wejnert, Barbara, and Metta Spencer. 1996. Women in

Post-Communist Countries. JAI Press.

World International League for Peace and Freedom (WILPF). 2015. The Solidarity of the

Women's Movement: Wilpf Spain's Contribution. http://wilpf.org/the-solidarity-of-thewomens-

movement-wilpf-spains-contribution

Wejnert, B. and Spencer, M. 1996, 'Women in PostCommunist Countries', JAI Press.

World International League for Peace and Freedom (WILPF), 2015, 'The Solidarity of the
Women's Movement: Wilpf Spain's Contribution', $<$ http://wilpf.org/the-solidarity-of-thewomensmovement-wilpf-spains-contribution>

Wolf, M. 2001, 'Will the nation-state survive globalization? Foreign Affairs, pp. 178-190.

Wu, Xiaoping, 2014, 'The Market Economy, Gender Equality, and Women's Development from the Viewpoint of Women's Employment', Chinese Education and Society, vol. 33, no.6, pp.44-54. Zherebkina, I. 2000, 'Prochti moi Zhelanye (Almost my Wishes)', Moscow: Ider Press. 